\title{
PENGARUH PARTISIPASI GURU DALAM PENGAMBILAN KEPUTUSAN DAN IMPLEMENTASI PENGAWAS TERHADAP KINERJA GURU
}

\author{
Edeh Sahidah $^{1,}$ Dety Mulyanti ${ }^{2}$ \\ ${ }^{1,2}$ Universitas Sangga Buana YPKP Bandung \\ ${ }^{1}$ korespondensi : aiadahrahmani@gmail.com
}

\begin{abstract}
This study aims to obtain information on the performance of MTs teachers in the KKM MTsN Cimerak: (1) teacher participation in making decisions on teacher performance. (2) the effect of teacher participation in the implementation of supervision on teacher performance. (3) Is there a relationship between teacher participation in decision making and implementation of supervision on teacher performance. The research method uses descriptive-correlational method. Data collection by observation and questionnaire to 30 respondents. The results of the study concluded: (1) The results of testing using the Spearman's Rho Correlation Test between Variable $X_{I}$ (Teacher Participation in Decision Making) with Y Variable (Teacher Performance), obtained the Spearmen's Rho Correlation Coefficient of 0.685, means a moderate correlation. (2) The test results using Pearson Product Moment Correlation Test between Variable $X_{2}$ (Teacher Participation in Supervision Implementation) with Y Variable (Teacher Performance), obtained Pearson correlation coefficient ( $r$ ) of 0.804 , highly correlated. (3) The results of testing using the multiple correlation test for Variables $X_{1}$ and $X_{2}$ with Variable $Y$, the double correlation coefficient $(r)$ is 0.848 , which means high correlation. Based on the test results the significance level is 0,000, which means far below 0.05. Thus, it can be concluded that there is a positive influence between teacher participation in joint decision making and teacher participation in the implementation of supervision of performance improvement in MTs throughout the MTsN Cimerak KKM.
\end{abstract}

Keywords: Teacher Participation, Decision Making, Teacher Performance

\begin{abstract}
ABSTRAK
Penelitian ini bertujuan untuk memperoleh informasi kinerja guru MTs se-KKM MTsN Cimerak: (1) partisipasi guru dalam pengambilan keputusan terhadap kinerja guru. (2) pengaruh partisipasi guru dalam implementasi pengawasan terhadap kinerja guru. (3) Apakah ada hubungan antara partisipasi guru dalam pengambilan keputusan dan implementasi pengawasan terhadap kinerja guru. Metode penelitian menggunakan metode deskriptif-korelasional. Pengumpulan data dengan observasi dan kuisioner kepada 30 responden. Hasil penelitian disimpulkan: (1) Hasil pengujian dengan menggunakan Uji Korelasi Spearman's Rho antara Variabel $X_{1}$ (Partisipasi Guru dalam Pengambilan Keputusan) dengan Variabel Y (Kinerja Guru), diperoleh koefisien Korelasi Spearmen's Rho sebesar 0,685, berarti korelasi sedang. (2) Hasil pengujian dengan menggunakan Uji Korelasi Product Moment Pearson antara Variabel $X_{2}$ (Partisipasi Guru dalam Implementasi Pengawasan) dengan Variabel Y (Kinerja Guru), diperoleh koefisien korelasi Pearson (r) sebesar 0,804, berkorelasi tinggi. (3) Hasil pengujian dengan menggunakan Uji Korelasi ganda terhadap Variabel $X_{1}$ dan $X_{2}$ dengan Variabel $Y$, diperoleh angka koefisien korelasi ganda $(r)$ adalah 0,848 yang berarti korelasi tinggi. Berdasarkan hasil pengujian tersebut tingkat signifikansinya adalah 0,000 yang berarti jauh di bawah 0,05. Dengan demikian, dapat disimpulkan bahwa terdapat pengaruh positif antara partisipasi guru dalam pengambilan keputusan secara bersama-sama dengan partisipasi guru dalam implementasi pengawasan terhadap peningkatan kinerja di MTs se-KKM MTsN Cimerak.
\end{abstract}

Kata Kunci: Partisipasi Guru, Pengambilan Keputusan, Kinerja Guru.

\section{PENDAHULUAN}

Pendidikan tumbuh bersama dengan

munculnya manusia, munculnya hal ini menunjukkan bahwa pendidikan merupakan suatu kebutuhan yang paling hakiki bagi kelangsungan hidup manusia. Melalui pendidikan sosial budaya dapat dilestarikan karena pendidikan memiliki komponen 
pokok dan aktivitas permasalahan yang mengarah pada tercapainya tujuan. Tujuan pendidikan Islam pada hakikatnya mengandung pilihan ke arah proses pencapaian nilai-nilai yang telah ditetapkan. Pendidikan akan mendukung pertumbuhan manusia dalam semua aspeknya. Guru memiliki tugas untuk mendidik, mengajar, memberikan teladan, dengan memiliki kompetensi akademik maupun kompetensi pendukung. Pendidik dituntut untuk mampu mengaplikasikan teori-teori pendidikan yang telah diketahui. Guru profesional memiliki upaya dalam meningkatkan keahlian dan kapasitas diri secara terus-menerus yang bertujuan membangun manusia sesuai dengan cita-cita bangsa. Fungsi dan peran guru sebagai pemimpin akan berhasil apabila guru memiliki kepribadian dengan tubuh yang sehat, mempunyai rasa percaya diri, memiliki daya kerja yang besar, antusiasme, dan dapat mengambil keputusan dengan tepat, dapat objektif dan mampu mengontrol emosi serta berlaku adil. Kepemimpin seorang guru mempunyai sifat, kebiasaan, temperamen, watak dan kepribadian sendiri yang unik dan khas sehingga tingkah laku dan gayanya yang membedakan dirinya dari orang lain.

Beberapa masalah yang dapat diidentifikasi dalam penelitian ini diantaranya; 1) setiap individu memiliki kebutuhan-kebutuhan yang tersusun secara hierarki, 2) hubungan atau komunikasi secara personal dan profesional memberi efek signifikan terhadap suksesnya pendidikan, 3) aspek kepimpinan bukan hanya perlu dimiliki oleh orang yang menempati posisi tertentu secara struktural, 4) kemampuan leadership yang cukup merata menjadi penting dalam membentuk sebuah kepemimpinan kolaboratif, 4) dibutuhkan kinerja guru yang profesional.

Rumusan masalah dalam penelitian ini adalah 1) bagaimana pengaruh partisipasi guru dalam pengambilan keputusan terhadap kinerja guru di MTs se-KKM Cimerak?, 2) bagaimana pengaruh Partisipasi guru dalam implementasi pengawasan terhadap kinerja guru di MTs se-KKM Cimerak?, 3) bagaimana pengaruh partisipasi guru dalam pengambilan keputusan dan implementasi pengawasan terhadap kinerja guru di MTs seKKM Cimerak?

Tujuan penelitian ini adalah mengetahui pengaruh partisipasi guru dalam pengambilan keputusan terhadap kinerja guru di MTs seKKM Cimerak, mengetahui pengaruh partisipasi guru dalam implementasi pengawasan terhadap kinerja guru di MTs seKKM Cimerak, dan mengetahui pengaruh antara partisipasi guru dalam pengambilan keputusan dan implementasi pengawasan terhadap kinerja guru di MTs. Se-KKM Cimerak.

Kegunaan penelitian secara teoritis berguna untuk menambah khazanah ilmu pengetahuan Manajemen pendidikan tentang faktor yang mempengaruhi kinerja guru. Sementara keguanaan secara praktis Berguna bagi Madrasah/ Sekolah dan memberikan infut bagi Departemen Agama RI serta para guru Madrasah Tsanawiyah dalam meningkatkan mutu Madrasah dan kinerja kepemimpinan kepada Madrasah dengan melibatkan guru 
dalam proses pengambilan keputusan dan pengawasan.

\section{TINJAUAN PUSTAKA}

Kepemimpinan adalah pelaksanaan otoritas dan pembuatan keputusan dalam rangka mencari jalan pemecahan dari suatu persoalan bersama. Kepemimpinan juga merupakan aktivitas untuk mempengaruhi orang-orang agar diarahkan mencapai tujuan organisasi [12]. Kepemimpinan adalah proses untuk mempengaruhi orang lain, baik dalam organisasi maupun di luar organisasi untuk mencapai tujuan. Prosesnya dipengaruhi dengan melibatkan berbagai kekuasaan (ancaman, penghargaan, otoritas, bujukan) [16].

Kepemimpinan tidak harus dibatasi oleh aturan-aturan atau tata krama birokrasi, tidak harus terjadi dalam suatu organisasi tertentu. Melainkan bisa terjadi di mana saja, asalkan seseorang menunjukkan kemampuannya agar terpengaruh pada perilaku untuk tercapainya tujuan. Apabila kepemimpinn itu dibatasai oleh tata krama atau dikaitkan terjadinya dalam suatu organisasi tertentu, maka dinamakan manajemen. Fungsi perencanaan (planning), pengaturan, motivasi dan pengendalian yang sering dipertimbangkan dalam proses pengambilan keputusan.

Dasar konseptual kepemimpinan menurut persfektif Islam. Ada 3 (tiga) pendekatan, yaitu normatif, historis dan teoritis. Pendekatan normatif bersumber pada AlQur'an dan Hadits yang terbagi atas 4 (empat) prinsip pokok, yaitu: 1) tanggungjawab dalam organisasi, 2) etika tauhid, 3) keadilan, dan 4) kesederhanaan.

Pemimpin yang berhasil hendaknya memiliki beberapa kriteria; pemimpin mempunyai sifat kepribadian, memiliki sifat dan keterampilan tertentu, serta memiliki seperangkat bakat tertentu. Pemimpin yang baik harus memiliki empat macam kualitas yaitu kejujuran, pandangan ke depan, mengilhami pengikutnya, dan kompeten.

Kepala sekolah berfungsi sebagai edukator (pendidik) harus memiliki strategi yang tepat untuk meningkatkan profesionalisme tenaga kependidikan di sekolahnya. Sebagai edukator, kepala sekolah harus senantiasa berupaya meningkatkan kualitas pembelajaran yang dilakukan oleh para guru. Adapun upaya-upaya yang dapat dilakukan kepala sekolah sebagai berikut: Pertama, guru ikut serta dalam penataran untuk menambah wawasan. Kedua, kepala sekolah dapat menggerakan untuk bekerja. Ketiga, menggunakan waktu belajar secara efektif untuk mendorong guru agar lebih berdisiplin waktu.

\section{Kepala Sekolah Sebagai Manajer}

Berikut peran dan fungsinya kepala sekolah sebagi manager: 1) memberdayakan tenaga pendidik dan kependidikan, 2) memberi kesempatan kepada tenaga pendidik dan kependidikan untuk meningkatkan profesinya, 3) mendorong partisipasi seluruh tenaga pendidik dan kependidikan, 4) pemberian hadiah (reward) bagi mereka yang berprestasi dan pemberian hukuman 
(punishment) bagi yang kurang disiplin dalam melaksanakan tugas.

\section{Kepala Sekolah Sebagai Administrator}

Memiliki hubungan yang lebih erat dengan berbagai aktivitas pengelolaan administrasi yang meliputi pencatatan, penyusunan dan pendokumenan seluruh program sekolah. Kepala Sekolah harus mampu mendeskripsikan dalam tugas-tugas operasional.

\section{Kepala Sekolah Sebagai Supervisor}

Yaitu melakukan supervisi pekerjaan yang dilakukan oleh guru, supervisi klinis untuk meningkatkan kemampuan professional guru dan meningkatkan kualitas pembelajaran melalui pembelajaran yang efektif. Adapun cirinya yaitu:

1) Diberikan berupa bantuan (bukan perintah).

2) Berdasarkan aspek usul guru, yang dikaji bersama Kepala Sekolah untuk dijadikan keputusan.

3) Instrument dan metode observasi dapat dikembangkan bersama.

4) Dapat berdiskusi dan menafsirkan hasil pengamatan dengan pendahuluan interpretasi guru.

5) Dilakukan dalam suasana terbuka secara tatap muka, lebih banyak mendengarkan serta menjawab pertanyaan dari pada memberikan saran dan pengarahan.

Kepala Sekolah sebagai supervisor harus memperhatikan prinsip yaitu hubungan konsultatif, kolegial dan bukan hirarkis, secara demokratis dilaksanakannya, guru sebagai pusat, sesuai dengan kebutuhan guru, bantuan operasional.

\section{Kepala Sekolah Sebagai Leader}

- Dapat memberikan petunjuk dan pengawasan,

- Kemampuan guru meningkat,

- Komunikasi dua arah

- Mendelegasikan tugas.

Kemampuan Kepala Sekolah terhadap tenaga Kependidikan yaitu (1) fahami kondisi, (2) fahami kondisi dan karakteristik peserta didik, (3) penyusunan program pengembangan tenaga kepedidikan, (4) saran dan kritik dapat diterima.

Kemampuan pengambilan keputusan: (1) pengambilan keputusan bersama tenaga kepedidikan di sekolah, (2) gagasan dalam bentuk tulisan, (3) melakukan komunikasi secara lisan dengan pesetra didik, orang tua dan masyarakat sekitar lingkungan sekolah.

\section{Kepala Sekolah Sebagai Inovator}

Akan tercermin dari caranya melakukan pekerjaan secara konstruktif, kreatif, delegatif, integratif, national dan objektif pragmatis, keteladanan, disiplin serta adaptable dan fleksibel.

Selain itu mempunyai kemampuan untuk mencari, menemukan dan melaksanakan berbagai pembaharuan di sekolah. Misalnya: moving class.

Moving class merupakan strategi dalam mengubah suatu pembelajaran dari pola kelas tetap menjadi kelas bidang studi yang memiliki kelas tersendiri yang di lengkapi dengan alat peraga dan alat alat lainnnya, 
yang bisa di padukan dengan pembelajaran terpadu.

\section{Kepala Sekolah Sebagai Motivator}

Dapat memberikan motivasi kepada para tenaga Kependidikan dalam melaksanakan berbagai tugas dan fungsinya. Motivasi ini dapat dilakukan melalui pengaturan fisik, suasana kerja, disiplin, dorongan, penghargaan secara efektif dan menyediakan berbagai sumber belajar melalui pengembangan pusat sumber belajar (PSB).

Partisipasi dalam kajian ilmu sosial politik tidak lepas dari teori struktural fungsional yang antara lain dibentuk. Dalam teori ini dikatakan bahwa realitas ideal dibentuk atas subsistem kebudayaan, subsistem sosial, subsistem kepribadian subsistem prilaku organik dan realitas fisik. Diantara subsistem tersebut memiliki hubungan timbal balik. Hubungan timbal balik antara realitas fisik dengan prilaku organik dilakukan melalui adaptasi, hubungan timbal balik antara prilaku organik dengan kepribadian dilakukan melalui melalui goal attainment hubungan timbal balik antara kepribadian dengan sistem sosial dilakukan melalui integrasi dan hubungan timbal balik antara sosial budaya dilakukan melalui latensi (membentuk pola) hubungan-hubungan timbal balik tersebut disebut teori Cibernatica.

Teori ini beranggapan bahwa persoalan manajemen guru di sekolah mencakup sebagai berikut:

1. Dalam melaksanakan program sekolah berapa banyak guru yang dibutuhkan?
2. Apakah setiap guru telah mendapatkan tugas sesuai dengan kemampuannya?

3. Apakah setiap guru produktif visioner inovatif matang dan mandiri?

4. Bagaimana sistem penggajian guru di sekolah?

5. Apakah kenaikan pangkat bagi guru terkelola dengan baik?

6. Bagaimana pembinaan kesejahteraan guru di sekolah dilakukan?

7. Bagaimana motivasi kerja guru dapat di tumbuh kembangkan secara continue?

8. Bagaimana suverpisi pembelajaran diprogramkan secara efektif dan efisien.

Cara cerdas mengambil keputusan yaitu; keputusan yang efektif, keputusan yang terbaik (the best), dan merumuskan faktorfaktor dalam mengambil keputusan.

Pengawasan merupakan proses dasar yang secara essential tetap diperlukan dalam suatu organisasi [18]. Prosesnya terdiri dari: (1) menetapkan standar dan pelaksanaan (2) pengukuran pelaksanaan pekerjaan dibandingkan dengan setandar dan (3) menentukan kesenjangan (deviasi) antara pelaksanaan dengan standar dan rencana. Sementara proses pengawasan yang tepat yaitu: a) penetapan standar pelaksanaan pekerjaan b) pengukuran hasil pekerjaan.

Kinerja guru dapat di nilai dari produktifitasnya yakni bagai mana melakukan pekerjan atau unjuk kerjannnya. Dalam hal ini produktifitasnya dapat di tinjau berdasarkan tingkatanya dengan tolok ukur yang berbeda. Yang dapat di lihat dari kinerja tenaga ke kependidikannya (guru) 
Kerangka berpikir yang lebih skematis sebagai berikut: 1) partisipasi guru dalam mengambil keputusan, pengambilan keputusan dalam sebuah lembaga adalah tugas dari seorang pemimpin dalam hal ini adalah Kepala Sekolah. Peranan pengambilan keputusan bertujuan menimbulkan perubahan yang menjadikan lembaga lebih baik. 2) partisipasi guru dalam pengawasan, peningkatan kerja di lingkungan kinerja akan dapat dicapai bila kegiatan pendidikan dan pembelajaran di sekolah berlangsung dengan baik berdaya guna dan berhasil guna. 3) kinerja, orang yang bekerja pada suatu instansi sudah selayaknya dinilai kerjanya. Partisipasi guru dalam dalam pengambilan keputusan dan implementasi pengawasan di lingkungan kerja dapat di lihat melalui hasil angket, untuk mengtahui meningkat tidaknya kinerja guru di MTs se-KKM MTsN Cimerak dengan angket isian kepada guru sebagai instrument penelitian.

Berdasarkan kerangka berpikir yang disusun tersebut di atas maka dapat di ajukan tiga hipotesis sebagai berikut:
1) Terdapat pengaruh positif antara partisipasi guru dalam pengambilan keputusan terhadap kinerja guru di MTs Se KKM MTs N Cimerak,

2) Terdapat pengaruh positif antara partisipasi guru dalam implementasi pengawasan terhadap peningkatan kinerja guru di, MTs Se KKM MTs N 2 Pangandaran,

3) Terdapat pengaruh positif antara partisipasi guru dalam pengambilan keputusan secara bersama-sama dengan partisipasi guru dalam implementasi pengawasan terhadap peningkatan kinerja di, MTs Se KKM MTs N Cimerak.

\section{METODE PENELITIAN}

Metode penelitian yang digunakan adalah metode korelasi yaitu penelitian deskriptif yang bertujuan untuk menetapkan besarnya hubungan antara variabel-variabel. Dengan populasi dalam penelitian ini adalah guru$\begin{array}{llllll}\text { guru } & \text { MTs } & \text { se-KKM } & \text { MTs } & \text { N } & 2\end{array}$ Pangandarandengan rincian sebagai mana dalam tabel berikut:

Tabel 1: Jumlah Guru di MTs se-KKM MTsN Cimerak

\begin{tabular}{|c|c|c|c|}
\hline No & Nama Sekolah & Jumlah Guru & Keterangan \\
\hline 1 & MTs N Cimerak & 18 & \\
\hline 2 & MTs S Ma'arif Curug & 12 & \\
\hline 3 & MTs S YPK Cijulang & 14 & \\
\hline 4 & MTs S Miftahul Ulum Ciakar & 12 & \\
\hline 5 & MTs S Legokjawa Cimerak & 11 & \\
\hline 6 & MTs. Kertaharja & 10 & \\
\hline & Jumlah & 77 & \\
\hline
\end{tabular}

Sumber : KKM MTs. Negeri Cimerak.

Populasi individu berjumlah 77 orang se-

KKM MTs N Cimerak, maka yang dijadikan sample penelitian sebanyak 30 orang.
Data data yang diperlukan dalam penelitian ini dikumpulkan dengan menggunakan tiga teknik, yaitu wawancara, kuesioner dan 
pengamatan. Namun demikian instrument utama yang di gunakan adalah kuesioner.

Instrument yang digunakan dalam penelitian ini ada tiga macam yaitu (1) instrument untuk mengetahui partisipasi guru dalam pengambilan keputusan $\left(\mathrm{X}_{1}\right)$, (2) instrument untuk mengukur variabel partisipasi guru dalam pengawasan kerja $\left(\mathrm{X}_{2}\right)$, (3) instrument untuk mengukur variabel kinerja guru.

\section{Instrumen variabel partisipasi guru dalam pengambilan keputusan $\left(\mathrm{X}_{1}\right)$}

Instrument yang digunakan adalah instrument tertutup yang dibuat berdasarkan definisi opersional pengambilan keputusan. Kisi-kisi instrument pengambilan keputusan sebagai berikut : 1) pengambilan keputusan efektif diantaranya; lingkungan yang efektif dan kondusif, individu yang kreatif-produktif, metode masalah solping yang ilmiah, memungkinkan untuk dilaksanakan. 2) metode yang digunakan dalam pengambilan keputusan yaitu; metode otoriter, metode konsultasi, metode musyawarah, metode termudah. 3) keputusan yang dikeluarkan meliputi; surat keputusan, menyempurnakan keputusan, perencanaan aksi, distribusi tanggung jawab, skedul waktu, anggaran.

Kisi-kisi instrument partisipasi guru dalam pengambilan keputusan sebagai berikut: 1) penentuan keputusan dengan dengan 6 item pertanyaan, 2) Metode yang digunakan dengan 10 item pertanyaan, 3) Kualifikasi keputusan kreatif dengan 11 item pertanyaan, dan 10 item pertanyaan. Sehingga berjumlah 36 pertanyaan.
Pengawasan adalah proses pengamatan pelaksanaan seluruh kegiatan organisasi untuk menjamin agar semua pekerjaan yang sedang dilakukan berjalan dengan mulus sesuai dengan perencanaan yang telah ditentukan sebelumnya. Secara operasional pengawasan kerja memiliki; 1) sasaran harus sesuai tujuan, sasaran harus sesuai rencana, menempatkan seseorang sesuai jabatan, prosedur kerja tidak menyimpang, pembagian tugas sesuai bidang dengan bidang secara objektif dan kondusif, tidak ada penyimpangan. 2) ciri pengawasan yang harus sesuai fakta, harus bersifat persektif, pada pekerjaan yang sedang berlangsung, untuk meningkatkan efesiensi, harus mempermudah mencapai tujuan, tidak menyalahkan tapi membenarkan, harus bersifat membimbing. 3) Teknik Pengawasan Langsung dan tidak langsung.

Kisi-Kisi Pengawasan Kerja $\left(\mathrm{X}_{2}\right)$ sebagai berikut: 1) sasaran-sasaran pengawasan dengan 8 item pertanyaan, 2) sifat-sifat pengawasan dengan 3 item pertanyaan, 3) Teknik-teknik pengawasan dengan 15 item pertanyaan. Sehingga berjumlah 36 pertanyaan.

Secara operasional. Kinerja guru meningkat apabila manusia bisa meningkatkan kualitas kehidupannya disegala bidang. Secara umum peningkatan produktifitas mengandung arti perbandingan yang dicapai (output) dengan keseluruhan sumber daya yang digunakan (input), yang berkaitan dengan sikap mental kerja hubungan dengan pemimpin, sikap mental, tingkat pendidikan, hubungan 
industrial, dan manajemen tenaga Kependidikan.

Kisi-Kisi Peningkatan Kinerja (Y) sebagai berikut: 1) produktivitas kerja dengan 8 item pertanyaan, 2) sikap mental dengan 3 item pertanyaan, 3) tingkat pendidikan dengan 2 item pertanyaan, 4) hubungan industrial dengan 16 item pertanyaan, 5) manajemen tenaga kependidikan dengan 7 item pertanyaan, sehingga berjumlah 36 pertanyaan.

Uji normalitas yang di gunakan pada penelitian yaitu uji Kolmogorov-smirnov. Sementara uji linieritas dan uji hipotesis terlebih dahulu dilakukan uji deskripsi data, uji prasyarat, uji analisis dan tahap pengujian hipotesis.

Pada tahap deskripsi data peneliti membuat tabulasi data untuk setiap variabel dengan mengurutkan data secara interval dan menyusunnya dalam bentuk tabel distribusi frekuensi, kemudian mencari rata-rata (mean) dan simpangan baku.

Uji persyaratan yang akan dilakukan adalah uji normalitas dan uji linieritas. Uji normalitas dilakukan agar dapat mengetahui data yang diteliti berdistribusi normal atau tidaknya, sedangkan uji homogenitas untuk memastikan kelompok data berasal dari populasi yang homogen. Uji normalitas menggunakan uji Lilifort-Shapiro-Wilkes atau uji Chi-Squer, sedangkan uji linieritas menggunakan regresi linier berganda.

Pengujian Hipotesis dilakukan dengan menggunakan analisis korelasi dan uji regresi. Uji keberartian menggunakan uji $\mathrm{t}$ dan uji $\mathrm{F}$ pada tarap signifikasi $\mathrm{a}=5 \%$ atau 0.05 .

Dari perhitungannya ditentukan koefisien korelasi $\mathrm{r}$ dan $\mathrm{R}$ serta persamaan regresi, sehingga dapat diketahui status hipotesis penelitiannya apakah diterima atau di tolak.

\section{HASIL DAN PEMBAHASAN}

\section{Deskripsi Data Variabel Partisipasi Guru} dalam Pengambilan Keputusan $\left(X_{1}\right)$

Kuisioner atau angket yang digunakan untuk mengumpulkan skor Variabel Partisipasi Guru dalam Pengambilan Keputusan $\left(\mathrm{X}_{1}\right)$ menggunakan konsep penilaian atau pengukuran ranah afektif. Hal ini didasarkan oleh pemikiran para akhli psikologi pendidikan, bahwa konsep partisipasi ini masuk dalam katagori ranah afektif. Ranah afektif meliputi sikap, persepsi, minat, konsep diri, nilai, dan moral.

Dengan instrumen yang memiliki item soal sebanyak 30 dengan menggunakan skala Likert 5 pilihan, maka skor tertinggi yang dapat diperoleh oleh responden penelitian ini adalah 5 X $30=150$, dan skor terendah yang dapat diperoleh responden adalah 1 X $30=$ 30 .

Berdasarkan hasil pengumpulan data terhadap 30 responden para guru Madraah Tsanawiyah se- KKM MTs Negeri Cimerak, dan setelah diolah dengan menggunakan komputer program SPSS for Windows Release 16.0.0., maka secara deskriftif hasil pengolahan data diketahui angka rata-rata (mean) Variabel Partisipasi Guru dalam Pengambilan Keputusan $\left(\mathrm{X}_{1}\right)$ adalah 86,500 
nilai minimum yang diperoleh responden 57,00 dan nilai maksimum yang diperoleh 111,00. Dengan nilai rata-rata (mean) 86,50 Maka kondisi objektif Partisipasi Guru dalam Pengambilan Keputusan di lingkungan Madrasah berada dalam katagori sedang.

\section{Deskripsi Data Variabel Partisipasi Guru} dalam Implementasi Pengawasan $\left(X_{2}\right)$

Data-data yang diperlukan untuk mengukur Variabel Keterlibtan Guru dalam Implementasi Pengawasan $\left(\mathrm{X}_{2}\right)$ menggunakan instrumen yang telah diuji validitas dan reliabilitasnya. Instrumen pengukuran Variabel Partisipasi Guru dalam Implementasi Pengawasan $\left(\mathrm{X}_{2}\right)$ ini memiliki item soal sebanyak 30 dengan menggunakan skala Likert 5 pilihan. Dengan demikian, maka skor tertinggi yang dapat diperoleh responden penelitian ini adalah 5 × $30=150$, dan skor terrendah yang dapat diperoleh responden hádala 1 x $30=30$.

Berdasarkan hasil pengumpulan data terhadap 30 responden para guru Madrasah Tsanawiyah se- KKM MTs Negeri Cimerak, dan setelah diolah dengan menggunakan komputer program SPSS for Windows Release 16.0.0., maka secara deskriptif hasil pengolahan data diketahui mean Variabel Partisipasi Guru dalam Implementasi pengawasan $\left(\mathrm{X}_{2}\right)$ adalah 80,166 nilai minimum responden 54,00 dan nilai maksimum 109,00. Dengan nilai mean 80,166. Maka kondisi objektif Partisipasi Guru dalam Implementasi Pengawasan di Madrasah berada dalam katagori sedang.
Deskripsi Data Variabel Kinerja Guru (Y)

Data Variabel Kinerja Guru juga dikumpulkan denga menggunakan kuesioner yang sebelumnya telah diuji validitas dan riliabilitasnya. Kuesioner yang digunakan untuk mengumpulkan skor Variabel $\mathrm{Y}$ memiliki item soal sebanyak 30 nomor berdasarkan skala Likert 5 pilihan. Skor tertinggi yang dapat diperoleh oleh responden adalah 5 × $30=150$, dan skor terendah yang dapat diperoleh responden $1 \mathrm{x}$ $30=30$. Secara deskriptif hasil pengumpulan data terhadap 30 responden para Guru Madrasah Tsanawiyah se- KKM Cimerak dapat hasil pengolahan menunjukkan angka rata-rata Variabel Kinerja Guru (Y) adalah 82,833 dengan nilai minimum responden 53,00 dan nilai maksimum responden 101,00. Dengan nilai rata-rata 82,833 . maka kondisi objektif Kinerja Guru di lingkungan Madrasah Tsanawiyah se- KKM Cimerak berada dalam kategori sedang.

\section{Uji Normalitas Variabel $\mathbf{X}_{1}$}

Uji normalitas menggunakan Program Komputer SPSS, Jenis uji yang digunakan adalah uji normalitas Kolmogorov Smirnov. Pemilihan jenis uji ini karena responden penelitian ini tidak terlalu banyak, yakni di bawah 100. Hasil uji normalitas terhadap Variabel $\mathrm{X}_{1}$ diperoleh skor statistik Kolmogorov-Smirnov sebesar 0,614 dengan nilai signifikansi sebesar 0,845 . Ketentuan pengambilan kesimpulannya adalah: a) Jika nilai probabilitas atau nilai signifikansi (Asymp.Sig) > 0,05, maka statu variabel berdistribusi normal. b) Jika nilai probabilitas 
atau nilai signifikansi (Asymp.Sig) $<0,05$, maka statu variabel tidak berdistribusi normal.

Karena nilai probabilitas atau nilai signifikansi (Asymp.Sig) 0,845, yang berarti lebih besar dari 0.05, maka dapat disimpulkan bahwa Variabel $\mathrm{X}_{1}$ penelitian ini berdistribusi normal. Hal itu juga dibuktikan dengan grafik histogram yang mendekati normal

\section{VAR00001}

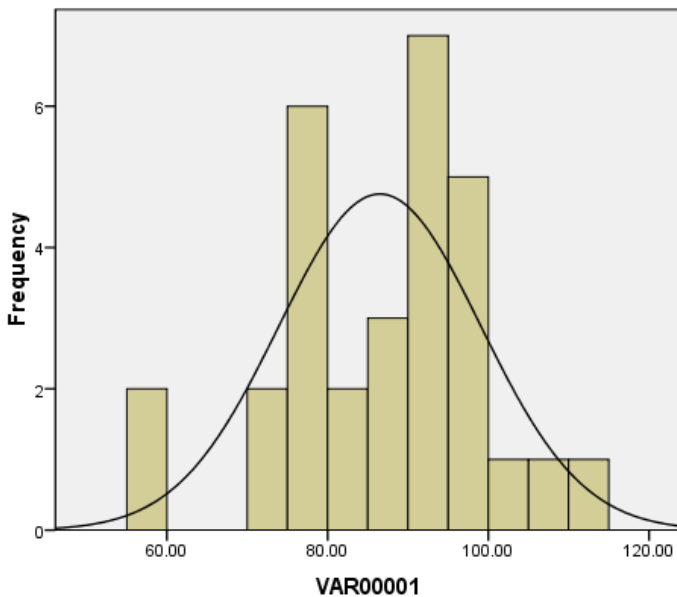

$\begin{aligned} & \text { Mean }=86.50 \\ & \text { Std. Dev. }=12.577 \\ & N=30\end{aligned}$

Gambar 1 : Grafik Histogram Variabel $X_{1}$

Uji Normalitas Variabel $\mathbf{X}_{\mathbf{2}}$

Pengujian terhadap distribusi skor Variabel $\mathrm{X}_{2}$ juga menggunakan jenis uji Normalitas Kolmogorov Smirnov, ini karena responden penelitian ini di bawah 100 orang. Pengujian normalitas terhadap Varibel $\mathrm{X}_{2}$ diperoleh hasil skor statistik Kolmogorov-Smirnov sebesar 0,809 dengan nilai signifikansi 0,529. Sesuai dengan ketentuan, karena nilai probabilitas atau signifikansi (Asymp.Sig) 0,529 , yang berarti lebih besar dari 0,05 , maka dapat disimpulkan bahwa skor-skor variabel $\mathrm{X}_{2}$ penelitian ini berdistribusi normal. Hal itu juga dibuktikan dengan grafik histogram yang mendekati normal, sebagaimana terlihat pada gambar di bawah ini:

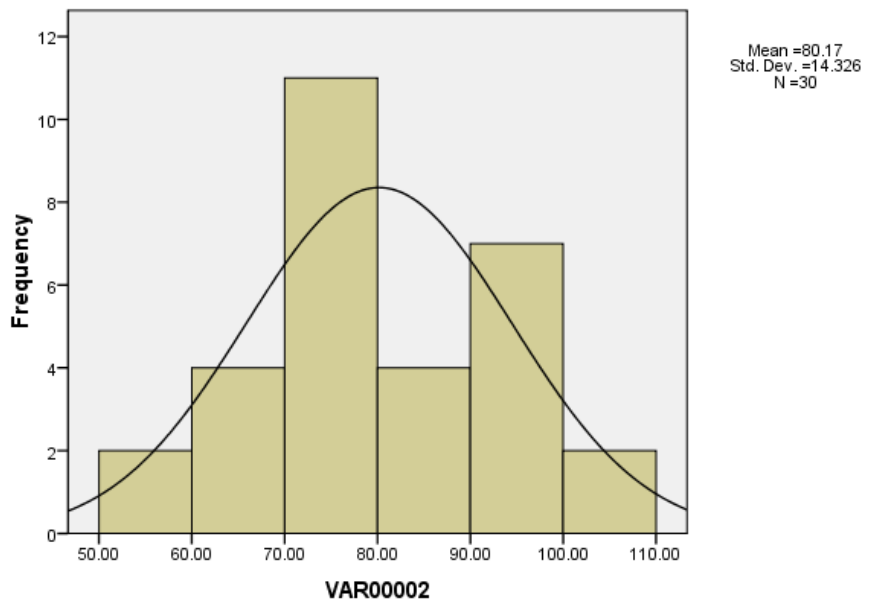

Gambar 2 : Grafik Histogram Variabel $X_{2}$ 


\section{Uji Normalitas Variabel Y}

Pengujian terhadap distribusi skor Variabel Y juga menggunakan jenis uji yang sama, yaitu Uji Normalitas Kolmogorov-Smirnov, diperoleh skor statistik Kolmogorov-Smirnov sebesar 0,891 dengan nilai signifikansi 0,406. Sesuai dengan ketentuan, karena nilai probabilitas/signifikansi (Asymp.Sig) 0,406,

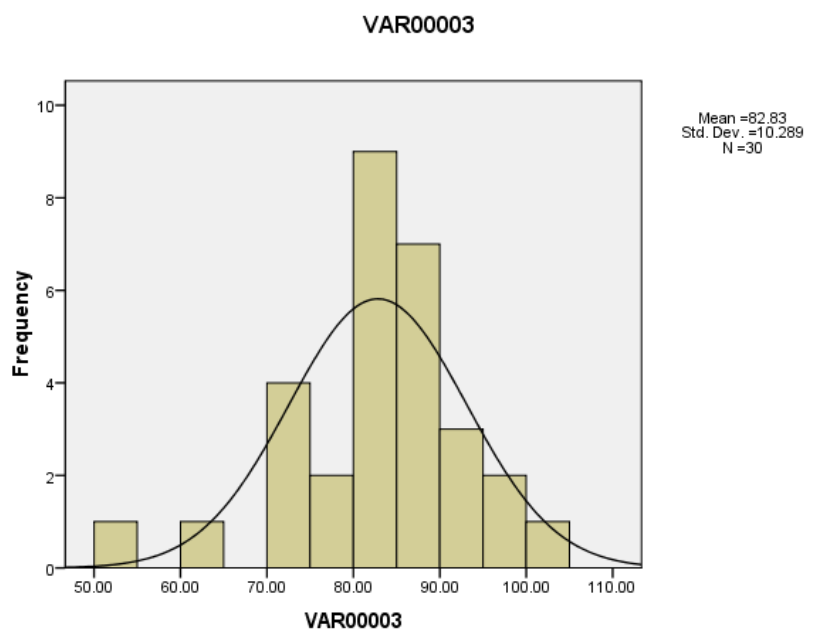

yang berarti jauh lebih besar dari 0,05, maka dapat disimpulkan bahwa skor-skor Variabel Y penelitian ini berdistribusi normal. Hal itu juga dibuktikan dengan grafik histogram yang mendekati normal, sebagaimana terlihat pada gambar di bawah ini:

\section{Gambar 3 : Grafik Histogram Variabel Y}

Hipotesis yang diajukan dalam penelitian ini ada tiga, yaitu:

Pertama, terdapat pengaruh positif antara partisipasi guru dalam pengambilan keputusan dengan kinerja guru Madrasah Tsanawiyah se- KKM MTs Negeri Cimerak.

Kedua, terdapat pengaruh positif antara partisipasi guru dalam implementasi pengawasan dengan kinerja guru Madrasah Tsanawiyah se-KKM MTs Negeri Cimerak Ketiga, terdapat pengaruh positif antara partisipasi guru dalam pengambilan keputusan, partisipasi guru dalam implementasi pengawasan secara bersamasama dengan kinerja guru Madrasah Tsanawiyah se KKM MTs Negeri Cimerak.
Hipotesis pertama yang diuji berkaitan dengan dua variabel, yaitu Variabel $\mathrm{X}_{1}$ (Partisipasi Guru dalam Pengambilam Keputusan) dan Variabel Y (Kinerja Guru Hasil pengujian dengan menggunakan Uji Korelasi Spearman's Rho terhadap Variabel $\mathrm{X}_{1}$ dengan Variabel $\mathrm{Y}$, memperlihatkan bahwa koefisien korelasi Spearman's Rho adalah 0,685, yang berarti korelasi sedang, sesuai dengan teori pengambilan kesimpulan yang berkaitan dengan angka koefisien korelasi:

$<0,20$ : Korelasi Sangat rendah

$0,20-0,40 \quad$ : Korelasi rendah

$0,40-0,70 \quad$ : Korelasi sedang

$0,70-0,90 \quad$ : Korelasi tinggi

$0,90-1,00 \quad$ : Korelasi sangat tinggi 
Karena memiliki angka koefisien korelasi sedang, maka dapat dikatakan bahwa hubungan antara partisipasi guru dalam pengambilan keputusan dengan kinerja guru Madrasah Tsanawiyah se KKM MTs Negeri Cimerak cukup erat.

Berdasarkan hasil pengujian tersebut dapat disimpulkan bahwa hipotesis pertama yang diajukan yang berbunyi: "Terdapat pengaruh positif antara partisipasi guru dalam pengambilan keputusan dengan kinerja guru Madrasah Tsanawiyah se KKM MTs Negeri Cimerak" diterima.

Hipotesis kedua yang diuji berkaitan dengan dua variabel, yaitu Variabel $\mathrm{X}_{2}$ (Partisipasi Guru dalam Implementasi Pengawasan) dan Variabel Y (Kinerja Guru). Karena kedua variabel berdistribusi normal, maka pengujian terhadap hipotesis kedua ini dapat dilakukan dengan uji korelasi parametri, dalam hal ini Uji Korelasi Product Moment Pearson. Hasil pengujian dengan menggunakan Uji Korelasi Product Moment Pearson terhadap Variabel $\mathrm{X}_{2}$ dengan Variabel Y, memperlihatkan bahwa bahwa koefisien korelasi Product Moment Pearson (r) adalah 0,804 yang berarti korelasi tinggi. Karena koefisien korelasi tinggi, maka dapat dikatakan bahwa hubungan antara partisipasi guru dalam implementasi pengawasan dengan kinerja guru Madrasah Tsanawiyah se KKM MTs Negeri Cimerak sangat erat. Berdasarkan hasil pengujian tersebut juga terlihat bahwa tingkat signifikansinya adalah 0,000 yang berarti jauh di bawah 0,05 . Maka hipotesis kedua yang diajukan yang berbunyi: "Terdapat pengaruh positif antara partisipasi guru dalam implementasi pengawasan dengan kinerja guruMadrasah Tsanawiyah se-KKM MTs Negeri Cimerak" diterima.

Dengan demikian dapat dikatakan semakin tinggi partisipasi guru dalam implementasi pengawasan, maka akan semakin tinggi pula kinerja para guru.

Hipotesis ketiga yang diuji berkaitan dengan tiga variabel, yaitu Variabel $\mathrm{X}_{1}$ (Partisipasi Guru dalam Pengambilan Keputusan), Variabel $\mathrm{X}_{2}$ (Partisipasi Guru dalam Implementasi Pengawasan) dan Variabel $\mathrm{Y}$ (Kinerja Guru). Karena ada tiga variabel yang diuji, maka pengujiannya dilakukan denga mmenggunakan uji korelasi ganda (multiple correlation). Hasil pengujian dengan menggunakan Uji Korelasi ganda (multiple correlation) terhadap Variabel $\mathrm{X}_{1}$ dan $\mathrm{X}_{2}$ dengan Variabel $\mathrm{Y}$, memperlihatkan bahwa koefisien korelasi ganda (multiple correlation) (R) adalah 0,848 , yang berarti korelasi tinggi. Karena koefisien korelasi tinggi, maka dapat dikatakan bahwa pengaruh antara partisipasi guru dalam pengambilan keputusan dan partisipasi guru dalam implementasi pengawasan dengan kinerja guru Madrasah Tsanawiyah se KKM MTs Negeri Cimerak sangat erat.

Berdasarkan hasil pengujian tersebut juga terlihat bahwa tingkat signifikansinya adalah 0,000 yang berarti jauh di bawah 0,05 . Maka hipotesis ketiga yang diajukan yang berbunyi: "Terdapat pengaruh positif antara partisipasi guru dalam pengambilan keputusan dan partisipasi guru dalam implementasi pengawasan dengan kinerja 
guruMadrasah Tsanawiyah se-KKM MTs Negeri Cimerak" diterima.

Dalam kaitannya dengan penelitian ini, maka partisipasi guru dalam pengambilan keputusan terkait dengan tiga komponen utama, yaitu: Pertama, kesempatan dalam pengambilan keputusan, ditandai dengan (a) kesediaan pemimpin dalam memberikan kesempatan kepada guru; (b) kesediaan guru dalam pengambilan keputusan. Kedua, partisipasi guru dalam pengambilan keputusan yaitu (a) memiliki kemampuan untuk mengemukakan pendapat di dalam pengambilan keputusan, dan (b) menerima pendapat orang lain sebagai masukan. Ketiga, yang melaksanakan keputusan, yaitu (a) kesediaan dan (b) kemandirian.

Selain partisipasi guru dalam pengambilan keputusan, hasil penelitian ini menunjukkan bahwa partisipasi guru dalam implementasi pengawasan memiliki hubungan positif yang sedang dengan kinerja guru.

Dengan demikian, Kepala Madrasah sebagai penggerak untuk melibatkan guru dalam pengambilan keputusan dan dalam implementasi pengawasan dapat terwujud apabila unsur yang relevan ini dikerjakan, yaitu (1) kesempatan untuk ikut dalam pengambilan keputusan dan implementasi pengawasan tercermin dalam kesediaan pimpinan memberi kesempatan kepada guru, (2) kesediaan guru dalam pengambilan keputusan dan implementasi pengawasan yang tercermin pada kemampuan mengemukakan pendapat dan kesediaan menerima pendapat orang lain, implementasi keputusan yang tercermin pada guru untuk ikut bertanggungjawab, kesesuaian pelaksanaan keputusan, dan kemandirian dalam melaksanakan keputusan. Sehingga harus saling mendukung, memberikan informasi terkait ide, pengetahuan, dan yang dianggap bermanfaat sebagi penunjang tugas-tugas guru. Proses pemenuhan kinerja guru Madrasah Tsanawiyah se-KKM MTs Negeri Cimerak jelas kelihatan bahwa partisipasi guru dalam pengambilan keputusan dan implementasi pengawasan cukup besar pengaruhnya.

\section{KESIMPULAN}

Hasil pengujian dengan menggunakan Uji Korelasi Spearman's Rho antara Variabel $\mathrm{X}_{1}$ (Partisipasi Guru dalam Pengambilan Keputusan) dengan Variabel Y (Kinerja Guru), memperoleh koefisien korelasi sedang. Berdasarkan hasil pengujian tersebut dapat disimpulkan bahwa hipotesis pertama yang diajukan yang berbunyi: "Terdapat pengaruh positif antara partisipasi guru dalam pengambilan keputusan dengan kinerja guru Madrasah Tsanawiyah se KKM MTs Negeri Cimerak" diterima.

Hasil pengujian dengan menggunakan Uji Korelasi Product Moment Pearson antara Variabel $\mathrm{X}_{2}$ (Partisipasi Guru dalam Implementasi Pengawasan) dengan Variabel Y (Kinerja Guru), memperoleh angka koefisien korelasi tinggi. Karena koefisien korelasi tinggi, maka dapat dikatakan bahwa pengaruh antara partisipasi guru dalam implementasi pengawasan dengan kinerja guru Madrasah Tsanawiyah se KKM MTs 
Negeri Cimerak cukup erat. Dengan demikian, dapat disimpulkan bahwa hipotesis kedua yang diajukan yang berbunyi: "Terdapat pengaruh positif antara partisipasi guru dalam implementasi pengawasan dengan kinerja guru Madrasah Tsanawiyah se-KKM MTs Negeri Cimerak “ diterima. Dengan demikian dapat dikatakan semakin tinggi partisipasi guru dalam implementasi pengawasan, maka akan semakin tinggi pula kinerja para guru.

Hasil pengujian dengan menggunakan Uji Korelasi ganda (multiple correlation) terhadap Variabel $\mathrm{X}_{1}$ dan $\mathrm{X}_{2}$ dengan Variabel $\mathrm{Y}$, diperoleh angka koefisien korelasi ganda (multiple correlation) tinggi. Dengan demikian, dapat disimpulkan bahwa hipotesis ketiga yang diajukan yang berbunyi: "Terdapat pengaruh positif antara partisipasi guru dalam pengambilan keputusan dan partisipasi guru dalam implementasi pengawasan dengan kinerja guru Madrasah Tsanawiyah se-KKM MTs Negeri Cimerak " diterima.

\section{DAFTAR PUSTAKA}

[1] Ali Mahmud,Guru dalam Proses Belajar Mengajar, Bandung: Sinar Baru Algesindo, 2002.

[2] Al-Hamdani Djaswidi, Pengembangan Kepemimpinan Transformasional pada Lembaga Pendidikan Islam, Bandung: Nuansa Aulia. 2005.

[3] Ath-Thuwairaqi, Nawwal, Sekolah Unggulan Berbasis Sirah Nabawiyah. Jakarta : Darul Falah. 2004

[4] Atmodiwino, Ubagio, Manajemen Pendidikan Indonesia. Jakarta : Ardadizia Jaya, 2000.
[5] Bafadal Ibrahim. Peningkatan Profesionalisme Guru. Jakarta : Bumi Aksara.

[6] Bass B. M., Leadership and Performance Beyond Exfectations, New York : Free Press, 1990.

[8] Danim Sudarwam, Menjadi Komunitas Pembelajar : Kepemimpinan Transformasional dalam Komunitas Organisasi Pembelajaran. Jakarta: Bumi Aksara, 2003.

[9] Darajat Zakiah. 1994. Pendidikan Islam dalam Keluarga. Jakarta : Ruhama.

[10] Departemen Agama RI, Standar Kompetensi Guru PAI. Jakarta : Depag. 2004.

[11] Donal Ary at.al, Pengantar Penelitian dalam Pendidikan, diterjemahkan oleh Arif Furchon. Yogyakarta ; Pustaka Pelajar, 2004

[12] Dubin Robert. Human Relation in Administrasion The Sosiologi of Organisation : with Reading and Cases. New York : Prentice Hand Book Company.

[13] Engkoswara, Paradigma Manajemen Pendidikan, menyongsong Otonomi Daerah. Bandung: Yayasan Amal, 2004

[14] E. Mulyasa,Manajemen Berbasis Sekolah. Bandung: Remaja Rosda Karya, 2002.

[15] E. Koswara, E, Sejarah Perkembangan Manajemen. Jakarta : Bulan Bintang, 2003

[16] Kartono Kartini, Pemimpin Kepemimpinan, Jakarta PT. Raja Grafindo Persada, 2003

[17] Fakih, Aunur Rohim dan Iip Wiyanto. 2001. Yogyakarta: Kepemimppinan Islam VII, Press.

[18] Murdick, 2012 